\title{
The Role of Employee Engagement in Mediating Perceived Organizational Support for Millennial Employee Organizational Citizenship Behavior
}

\author{
Ellen Priskila, Melitina Tecoalu, Saparso, and Hery Winoto Tj \\ Faculty of Economics and Business, Krida Wacana Christian University, Indonesia \\ Faculty of Economics and Business, Krida Wacana Christian University, Indonesia \\ Faculty of Economics and Business, Krida Wacana Christian University, Indonesia \\ Faculty of Economics and Business, Krida Wacana Christian University, Indonesia \\ Email: ellen.priskila@yahoo.com, melitina@ukrida.ac.id, saparso@ukrida.ac.id, and \\ hery.winoto@ukrida.ac.id
}

\begin{tabular}{|c|c|}
\hline ARTICLE INFO & ABSTRACT \\
\hline $\begin{array}{l}\text { Date received : } 01 \\
\text { April } 2021 \\
\text { Revision date : } 04 \\
\text { March } 2021 \\
\text { Date received : } 16 \\
\text { May } 2021\end{array}$ & $\begin{array}{l}\text { The era of globalization is a time when competition becomes } \\
\text { increasingly tight, employees are required to be able to show extra work } \\
\text { behavior that can exceed the expectations of the organization (extra role } \\
\text { behavior). The existence of high initiative from employees is able to } \\
\text { improve the effectiveness of an organization, while employees who have } \\
\text { good organizational support will also form positive behavior as a form of } \\
\text { reciprocal support to the organization. Through employee engagement is }\end{array}$ \\
\hline $\begin{array}{l}\text { Keywords: } \\
\text { employee } \\
\text { engagement } \\
\text { perceived } \\
\text { organizational } \\
\text { support } \\
\text { organizational } \\
\text { citizenship behavior }\end{array}$ & $\begin{array}{l}\text { expected to strengthen the behavior of the organization's citizenship. In } \\
\text { Indonesia is currently entering the era of demographic bonuses, the } \\
\text { condition makes this research interesting to do in millennials. The } \\
\text { purpose of this study is to test the influence of employee engagement in } \\
\text { mediating perceived organizational support to the organizational } \\
\text { citizenship behavior of } 83 \text { millennial employees of PT Tatalogam Lestari. } \\
\text { Structural Equation Modelling (SEM) analysis techniques using SmartPLS } \\
\text { were used in this study. The results of the analysis stated that there is } \\
\text { an influence perceived organizational support, employee engagement } \\
\text { and organizational citizenship behavior. Employee engagement is also } \\
\text { proven to mediate the influence of perceived organizational support on } \\
\text { organizational citizenship behavior. This study found that the higher the } \\
\text { perception of organizational support in employees, the higher the sense } \\
\text { of attachment of employees with the organization, so as to encourage } \\
\text { the occurrence of organizational citizenship behavior in employees }\end{array}$ \\
\hline
\end{tabular}

\section{INTRODUCTION}

Employee behavior is very related to the performance of an organization and is the most important aspect that should be focused by the leader of the organization. Within the organization, every employee must have the same vision that is to achieve the goals of the organization. In work, employees can do work both formally (in accordance with the job description) and non-formal (outside of the job description). When an employee is involved in a job outside of his job description it is called organizational citizenship behavior (OCB). Such behavior is an initiative and choice of employees with the aim of improving productivity and efficiency of organizational performance (Organ et al., 2005). OCB behavior is behavior that exceeds the required role but does not become explicitly recognized as part of an employee's employment obligations (Tecualu, 2015). There are five dimensions of $O C B$ including conscientiousness, courtesy, civic virtue, sportsmanship, and altruism.

\begin{tabular}{ll} 
How to cite: & $\begin{array}{l}\text { Priskila, Ellen. et.al. (2021). The Role of Employee Engagement in Mediating Perceived } \\
\text { Organizational Support for Millennial Employee Organizational Citizenship Behavior. 2(3). } \\
\text { https://doi.org/10.46799/jsss.v2i3.129 }\end{array}$ \\
\hline E-ISSN: & $2721-5202$ \\
\hline Published by: & Ridwan Institute \\
\hline
\end{tabular}


Perceived Organizational Support (POS) i.e. a belief from employees that the organization values contributions and cares about the welfare of employees (Wu \& Liu, 2014). POS is able to assist karyawab in maximizing positive performance and minimizing negative performance as a form of reciprocal relationship between the organization and employees. Shore and Wayne in (Emanuel, 2011) found that POS was capable of being a predictor of OCB. (Rhoades \& Eisenberger, 2002) suggests that POS antecedents are fairness in the form of fair organizational procedures in the distribution of resources among employees, the support of superiors, as well as organizational awards and working conditions (salaries, bonuses, and others).

Judging from other aspects, employee engagement is an important factor to be studied in the business world today. according to (A. B. Bakker \& Demerouti, 2017), employees who are able to engage with their work will be able to produce productivity, innovation, and good performance. (Harter et al., 2002) explained that employee engagement is a form of involvement of a person and his satisfaction as a form of enthusiasm in work. Employee engagement is a positive behavior in work, able to complete the work with the thinking power described by vigor, dedication, and absorption. Vigor is a high level of energy in work. Dedication is an engagement that includes inspiration, pride, enthusiasm, and challenge. Absorption is the final dimension of engagement which is the condition in which employees are focused on a job.

Indonesia today is entering a period of demographic bonuses, which in this era is inseparable from the role of millennials. In this era, every employee is required to be able to show performance that can exceed the expectations of the organization. PT Tatalogam Lestari is a company engaged in the manufacturing sector in the Jakarta area. $75 \%$ of the company's employees are millennials. Based on observations, millennial employees in the company are able to apply OCB behavior in work. However, some other employees still find it difficult to implement the OCB behavior. Based on this phenomenon, in this study will be explored further related to the role of employee engagement in mediating the influence of perceived organizational support on OCB behavior in employees of PT Tatalogam Lestari, especially if reviewed in terms of millennials.

Tinjauan Teori Dan Pengembangan Hipotesis

1. Organizational Citizenship Behavior (OCB)

$\mathrm{OCB}$ is the conduct of an employee who is conducted voluntarily and sincerely without (Organ et al., 2005) dalam (Maryati \& Fernado, 2018). (Organ et al., 2005) explains that OCB is an individual contribution in depth beyond the demands of workplace roles and rewards based on performance. Organ, Podsakof, and Mackenzie in (Kusumajati, 2014), explains that OCB has five-dimensional Altruism, Conscientiousness, Civic Virtue, Courtesy, and Sportmanships.

2. Perceived Organizational Support (POS)

POS is a perspective on an employee's belief in the extent to which an organization is able to appreciate the contributions of its employees. (Rhoades et al., 2001). (Robbins et al., 2015) pos as a feeling of the extent to which employees believe that the organization is able to appreciate and care about their contributions. Antecedent POS as described (Rhoades \& Eisenberger, 2002) in (Ariarni \& Afrianty, 2017) among others:

a. Fairness: Organizations have fair procedures in the distribution of resources among employees.

b. Superior support: Supervisors have a responsibility to direct and evaluate the performance of their subordinates.

c. Organizational awards and working conditions: Includes salary, benefits, bonuses, promotions, training, development.

3. Employee Engagement

This concept is a positive employee treatment to the organization, where the value of the organization can be implemented by employees in realizing the goals of the organization (Robbins et al., 2015) in (Setiawan \& Widjaja, 2018). This concept can also be interpreted as the extent to which employees are encouraged to contribute to the success of the organization. (Albrecht, 2010). (A. Bakker et al., 2003) explaining there are three dimensions of employee 
engagement, among others, passion, dedication, and passion. Gallup Organization (Setiawan \& Widjaja, 2018) divide employee type based on their engagement level as engaged employees, actively disengaged employees, and not engaged employees.

\section{METHOD}

The target in this study is employees who work at the head office of PT Tatalogam Lestari, where a sample of 110 millennial employees was sampled. Based on that, the sampling technique used is purposive sampling. Data collection instruments using questionnaires that are shared directly with respondents. Data analysis in this study using SEM analysis with SmartPLS.

\section{RESULTS AND DISCUSSION}

By (Hair Jr et al., 2016), there are several stages in conducting analysis using SEM PLS, namely model specification testing (inner and outer model), reliability and validity testing, and structural model evaluation.
A. Pengujian Convergent \& Discriminant Validity

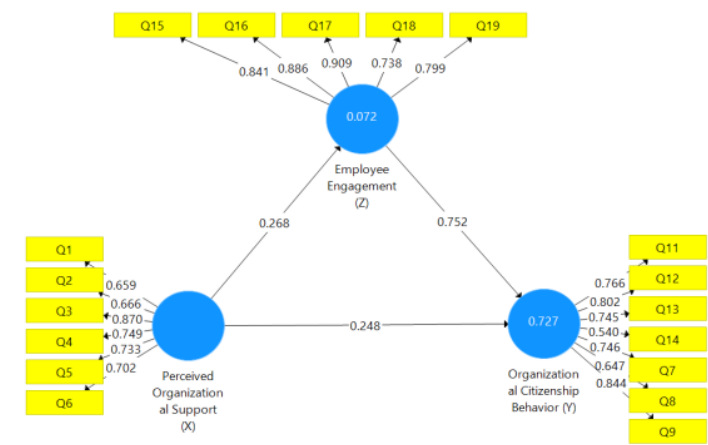

Source: SmartPLS data processing results

Figure 1. Loading Factor Value

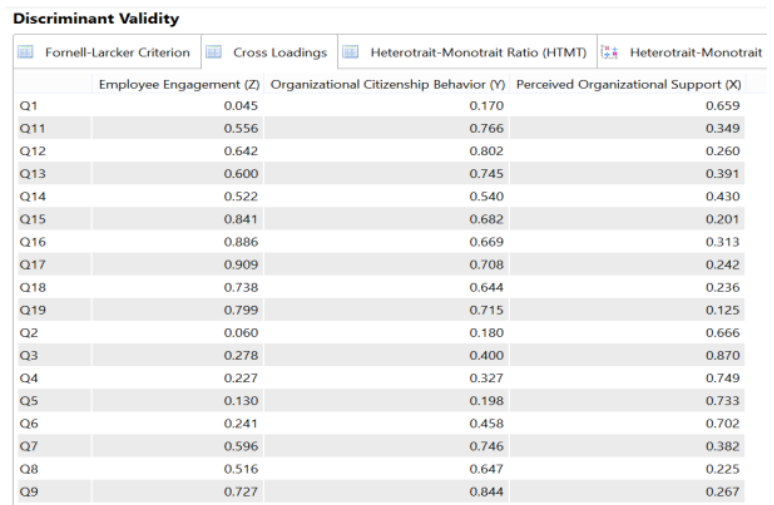

Source: SmartPLS data processing results

Figure 2. Cross Loadings

Average Variance Extracted (AVE)

\begin{tabular}{|l|l|}
\hline Employee Engagement $(Z)$ & 0.700 \\
\hline Organizational Citizenship Behavior $(Y)$ & 0.538 \\
\hline Perceived Organizational Support $(X)$ & 0.538
\end{tabular}

Based on the results of convergent test and discriminant validity obtained the results of factor loading values of each indicator above 0.5 . It can be concluded that the indicator is valid. In addition, the RESULT AVE value of each variable all shows a value greater than 0.5 where it can be stated that each variable has a good discriminant validity.

1. Composite Reliability Test

Composite Reliability

Employee Engagement (Z)

Organizational Citizenship Behavior ( $M$ )

Perceived Organizational Support (X)

Source : SmartPLS data processing results

Figure 5. Composite Reliability

The value of the above results shows the reliability test results of each variable of this study, which can be shown that the composite reliability value has met the criteria that is above 0.7 . It can be concluded that all research variables are reliable.

2. Coefficient Path Test

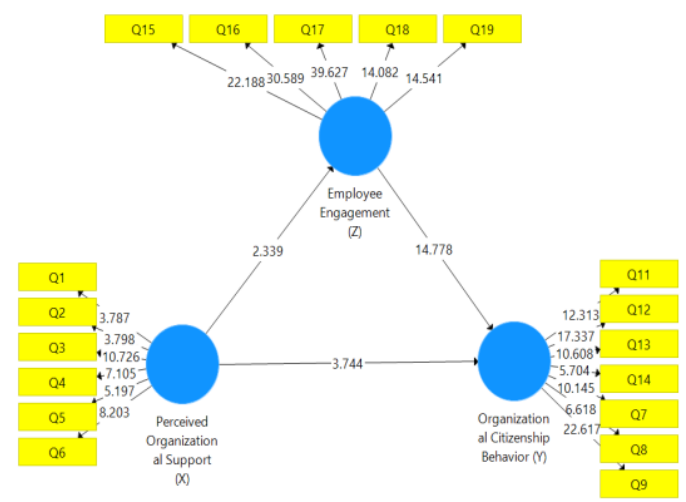

Source : SmartPLS data processing results

Figure 6. Bootstrapping Model 
The value of the coefficient of path in the model indicates the effect of employee engagement on OCB of 14,778 . While the influence of POS on OCB amounted to 3,744 and the influence of POS on employee engagement amounted to 2,339. Results showed that the overall model had a positive coefficient of path, meaning the influence between independent variables on dependents tended to be strong.

3. R-Square test

Based on the test of $r$-square value obtained results that the ability of POS variables in explaining employee engagement by $7.2 \%$ while the ability of POS variables in explaining OCB by $72.7 \%$ Hipotesis test

Path Coefficients

\begin{tabular}{|c|c|c|c|c|}
\hline \multicolumn{3}{|c|}{ 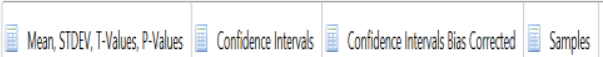 } & \multicolumn{2}{|c|}{ Copyto Cipboard: } \\
\hline & Original... Sample... S & andard. TSta & S|OSTDEY) & PValues \\
\hline 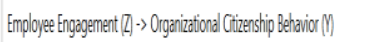 & $0.752 \quad 0.750$ & 0.051 & 14.778 & 0.000 \\
\hline 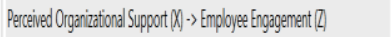 & $0.268 \quad 0302$ & 0.114 & 2339 & 0.020 \\
\hline 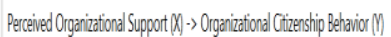 & $0248 \quad 0249$ & 0.066 & 3.74 & 0.0 \\
\hline
\end{tabular}

Source : SmartPLS data processing results

Figure 7. Hypothesis Test Results

\section{a. Hipotesis Test 2}

H1: POS affects OCB on millennial employees.

Based on the above results with a t-count value of $3,744<$ 1.96 , then hypothesis one can be accepted and proven which means that POS has a significant positive effect on OCB. Thus, employees' perception of organizational support can improve OCB behavior in employees of PT Tatalogam Lestari. This was supported by (Fauzy \& Luterlean, 2020) Maula \&A frianty (2017) who found that there was a positive and significant influence between POS and OCB. (Setiawan \& Widjaja, 2018) and (Aswin \& Rahyuda, 2017) also showed similar results that there was a significant influence between POS and OCB. It shows that if employees believe and feel the support and concern of the organization towards the welfare of employees then employees will contribute that exceeds the demands of their role at PT Tatalogam Lestari.

b. Hipotesis Test 2

H2: POS affects Employee Engagement on millennial employees.

Based on the results of tcount value of $2,339<1.96$, the second hypothesis can be accepted and proven which means that POS has a significant positive effect on employee engagement. Thus, if the employee experiences support from the organization towards the employee, it will affect the employee's support to the organization at PT Tatalogam Lestari. This is in line with the results of the (Ariarni \& Afrianty, 2017) and (Prawira, 2019), that there is a positive influence between POS and Employee Engagement. When employees feel that their contributions are appreciated, it will affect the support given to their organization. according to (Harter et al., 2002) employee engagement is a form of one's involvement, as well as satisfaction as a form of employee enthusiasm in work.

C. Hipotesis Test 3

$\mathrm{H} 3$ : Employee Engagement affect OCB on millennial employees.

Based on the results of the tcount value of $14,778<1.96$, the three hypotheses are accepted and can be proven which means that employee engagement has a significant positive effect on OCB. So it can be concluded that the level of employee engagement affects the level of employee OCB at PT Tatalogam Lestari. The higher the engagement rate, the higher the employee's OCB level. OCB is an individual choice and initiative in improving organizational performance efficiency (Organ et al., 2005). The test results reinforce the research conducted by (Amanda et al., 2014), (Tjahjaningsih, 2016), (Andriani, 2017) positive results for 
employee engagement and $\mathrm{OCB}$ variable relationships. Konrad, et al.. (Soegandhi, 2013) suggest that work behaviors such as helping others, being friendly and working together tend to be done by women rather than men. In the demographic data presented earlier, it can be seen that the number of female respondents is more than the number of male respondents, causing the dimension to be the most selected dimension. In addition, the conscientiousness dimension is also a dimension that many employees choose to do. Employees at PT Tatalogam Lestari work and strive to exceed what the company expects even though it is not its obligation. according to (Organ, 1994) OCB behavior can leave a positive impression on stakeholders in the organization that will ultimately lead to workplace benefits, such as raises or promotions. But besides, after being traced based on the item statement about civic virtue dimension not all respondents agreed to routinely follow the activities held meksipun organiasi basically it indicates responsibility on the life of the organization. This can be due to the cultural and climatic influences of the organization. By Internal Organs (Soegandhi, 2013) suggest that organizational culture is a key early condition in triggering ocb.

d. Hipotesis Test 4

$\mathrm{H} 4$ : Employee Engagement mediates the effect of POS on OCB on millennial employees.

The above result with a tcount value of 2,291 > 1.96 then the fourth hypothesis is acceptable and proven which means that employee engagement mediates the influence of POS on OCB. This means that employee engagement is able to strengthen the relationship between POS to OCB at PT Tatalogam Lestari. These results support research conducted by (Pertiwi, 2019) that employee engagement variables can mediate the effect of POS on OCB. (Gallup et al., 2006) define employee engagement as the involvement and enthusiasm of employees in completing their work. POS meets emotional social needs, resulting in greater identification and commitment to the organization, an increased desire to help the organization succeed, and greater psychological well-being. according to (Wulandari \& Yuniawan, 2017) employees who feel tied to the company, there will be a high insiative to do the maximum work. So it can be concluded that if employees at PT Tatalogam Lestari have a high POS level, then employees will provide positive reciprocity by being tied or engaged with the organization and their work so as to encourage OCB behavior in employees.

\section{CONCLUSION}

Based on the results of the analysis can be obtained the following conclusions:

1. POS affects OCB on millennial employees at PT Tatalogam Lestari. This result means that the better employee perception of organizational support can improve OCB behavior in employees of PT Tatalogam Lestari.

2. POS affects Employee Engagement on millennial employees at PT Tatalogam Lestari. Thus, it can be interpreted that if the employee feels the support from the organization towards the employee it will affect the employee's support to the organization at PT Tatalogam Lestari.

3. Employee Engagement affects OCB on millennial employees at PT Tatalogam Lestari. Therefore, the higher the employee engagement level at PT Tatalogam Lestari, the higher the LEVEL of OCB shown by employees.

4. Employee Engagement mediates the influence of POS on OCB on millennial employees at PT Tatalogam Lestari. Therefore, it can be interpreted that if 
employees at PT Tatalogam Lestari feel the support of the organization, then the employee will provide positive reciprocity by being bound or engaged with the organization and its work so as to encourage OCB behavior in employees.

Ocb behavior of millennial employees at PT Tatalogam Lestari is quite good where the behavior is influenced by perceived organizational support and employee engagement. Employee engagement can also mediate the influence of Perceived Organizational Support on Organizational Citizenship Behavior on millennial employees at PT Tatalogam Lestari.

\section{REFERENCES}

Albrecht, M. (2010). Cyclometalation using dblock transition metals: fundamental aspects and recent trends. Chemical Reviews, 110(2), 576-623. Google Scholar

Amanda, R., Birol, I., Bousquet, J., Ingvarsson, P. K., Jansson, S., Jones, S. J. M., Keeling, C. I., MacKay, J., Nilsson, O., \& Ritland, K. (2014). Insights into conifer giga-genomes. Plant Physiology, 166(4), 1724-1732. Google Scholar

Andriani, D. (2017). Pengaruh Gaya Kepemimpinan Transformasional, Budaya Organisasi Dan Lingkungan Kerja Terhadap Kinerja Karyawan PT." $\mathrm{X}^{\prime \prime}$ Sidoarjo. JBMP (Jurnal Bisnis, Manajemen Dan Perbankan), 2(2), 91102. Google Scholar

Ariarni, N., \& Afrianty, T. W. (2017). Pengaruh Perceived Organizational Support terhadap Kinerja Karyawan dengan Employee Engagement sebagai Variabel Intervening (Studi pada Karyawan PT. Pos Indonesia Kota Madiun). Jurnal Administrasi Bisnis, 50(4), 169-177. Google Scholar

Aswin, A. E., \& Rahyuda, A. G. (2017). Pengaruh Perceived Organizational Support Terhadap Organizational
Citizenship Behavior Dengan Variabel Kepuasan Kerja Sebagai Mediasi. EJurnal Manajemen, 6(5), 2729-2755. Google Scholar

Bakker, A. B., \& Demerouti, E. (2017). Job demands-resources theory: taking stock and looking forward. Journal of Occupational Health Psychology, 22(3), 273. Google Scholar

Bakker, A., Demerouti, E., \& Schaufeli, W. (2003). Dual processes at work in a call centre: An application of the job demands-resources model. European Journal of Work and Organizational Psychology, 12(4), 393-417. Google Scholar

Emanuel, A. (2011). Analisis Pengaruh Kepuasan Kerja, Loyalitas Karyawan dan Perilaku Organisasi Terhadap Organizational Citizenship Behavior Serta Dampaknya Terhadap Efektifitas Organisasi Pada PT. Wirajaya Anugrah Perkasa. Retrieved April, 30, 2012. Google Scholar

Fauzy, M. R., \& Luterlean, B. S. (2020). Pengaruh Internal Locus Of Control Dan Perceived Organizational Support Terhadap Organizational Citizenship Behavior Pada Karyawan Divisi Quality Control Di PT Leading Garment Industries. Jurnal IImiah MEA (Manajemen, Ekonomi, \& Akuntansi), 4(2), 22-35. Google Scholar

Gallup, A., Gallup, A. M., \& Newport, F. (2006). The Gallup Poll: Public Opinion 2005. Rowman \& Littlefield. Google Scholar

Hair Jr, J. F., Hult, G. T. M., Ringle, C., \& Sarstedt, M. (2016). A primer on partial least squares structural equation modeling (PLS-SEM). Sage publications. Google Scholar

Harter, J. K., Schmidt, F. L., \& Hayes, T. L. (2002). Business-unit-level relationship between employee satisfaction, employee engagement, and business outcomes: a meta-analysis. Journal of Applied Psychology, 872), 268. Google 
Scholar

Kusumajati, D. A. (2014). Organizational citizenship behavior (OCB) karyawan pada perusahaan. Humaniora, 5(1), 6270. Google Scholar

Maryati, T., \& Fernado, A. (2018). Peran Organizational Citizenship Behaviour (OCB) Dalam Memediasi Pengaruh Motivasi Intrinsik dan Kepuasan Kerja Terhadap Kinerja Karyawan pada PT. Cinemaxx Branch Lippo Plaza Yogyakarta. JBTI: Jurnal Bisnis: Teori Dan Implementasi, 9(2), 158-173. Google Scholar

Organ, D. W. (1994). Personality and organizational citizenship behavior. Journal of Management, 20(2), 465478. Google Scholar

Organ, D. W., Podsakoff, P. M., \& MacKenzie, S. B. (2005). Organizational citizenship behavior: Its nature, antecedents, and consequences. Sage Publications. Google Scholar

Pertiwi, B. R. (2019). Tinjauan Yuridis Pengangkutan Barang Melaui Laut Dalam Bill Of Lading. Universitas Ahmad Dahlan. Google Scholar

Prawira, J. (2019). Pengaruh Perceived Organizational Support Terhadap Employee Performance Melalui Employee Engagement CV Sumo Surya Perkasa di Lombok. Agora, ス1). Google Scholar

Rhoades, L., \& Eisenberger, R. (2002). Perceived organizational support: a review of the literature. Journal of Applied Psychology, 874), 698. Google Scholar

Rhoades, L., Eisenberger, R., \& Armeli, S. (2001). Affective commitment to the organization: The contribution of perceived organizational support. Journal of Applied Psychology, 86(5), 825. Google Scholar

Robbins, S. P., Judge, T. A., \& Millett, B.
(2015). OB: the essentials. Pearson Higher Education AU. Google Scholar

Setiawan, O. D., \& Widjaja, D. C. (2018) Analisa pengaruh Employee Engagement Terhadap Kinerja Karyawan dengan Kepuasan Kerja sebagai Variabel Intervening di ShangriLa Hotel Surabaya. Jurnal Hospitality Dan Manajemen Jasa, 6(2). Google Scholar

Soegandhi, V. M. (2013). Pengaruh kepuasan kerja dan loyalitas kerja terhadap organizational citizenship behavior pada karyawan PT. Surya Timur Sakti Jatim. Agora, 1(1), 808-819. Google Scholar

Tecualu, M. (2015). The Effect of Retail Service Quality (RSQ) and Organizational Citizenship Behavior (OCB) on Store Loyalty at The Minimart in Jakarta. Google Scholar

Tjahjaningsih, C. C. E. (2016). Pengaruh Employee Engagement Dan Modal Sosial Terhadap Kinerja Karyawan Dengan OCB (Organizational Citizenship Behaviour) Sebagai Mediasi (Studi pada Bank Jateng Kantor Pusat). Media Ekonomi Dan Manajemen, 30(2). Google Scholar

Wu, C.-C., \& Liu, N.-T. (2014). Perceived organizational support, organizational commitment and service-oriented organizational citizenship behaviors. International Journal of Business and Information, 9(1), 61. Google Scholar

Wulandari, A. D., \& Yuniawan, A. (2017). Analisis Pengaruh Dukungan Organisasi Dan Pengembangan Karir Terhadap Organizational Citizensip Behavior Dengan Employee Engagement Sebagai Variabel Intervening (Studi Pada Karyawan PDAM Tirta Moedal Kota Semarang). Diponegoro Journal of Management, 6(4), 102-115. Google Scholar 
Copyright holder:

Ellen Priskila, Melitina Tecoalu, Saparso, and Hery Winoto Tj (2021)

First publication right:

Journal of Social Science (JSS)

This article is licensed under:

(c) $\underset{\mathrm{EY}}{\mathrm{BY}}$ 